\title{
Political Participation in Amendment of Semarang Dugderan Market Location
}

\author{
Tri Lestari Hadiati ${ }^{1}$, Careza Rizky Ayuningtyas ${ }^{2}$ \\ \{liestarihadiati@gmail.com ${ }^{1}$ \} \\ Universitas 17 Agustus 1945 Semarang, Indonesia ${ }^{1}$ \\ Politeknik Negeri Semarang, Indonesia ${ }^{2}$
}

\begin{abstract}
This research is intended to analyze the political participation that is typical of the Kauman people in the context of local government political decision making, so that it can successfully lobby. People of Kauman in the city of Semarang, are known to have strong political participation in maintaining the location of the Dugderan market. During this time, they tried to keep holding a unique Dugderan market. But the city government made a political decision that changed the location of the Dugderan market (2016-2019). This causes the political participation of the people to crystallize and become more solid, in maintaining the market location so that it remains close to the Kauman Mosque in Semarang. This research method uses survey methods and qualitative research types. In dept interviews several times, then analyzed to find information and see appropriate political participation. The results of this study found a new way of voluntary but solid political participation in maintaining the location of the Dugderan market.
\end{abstract}

Keywords: Political Participation, Political Decision, Dugderan Market

\section{Introduction}

The position and role of the elite in state life is very important, because it becomes a shared need between the elite and the people, to maximize its role in creating res public (beneficial). Political participation can be formed through action processes in political decision making, both by the elite and the masses. Elite as the leader takes action to govern and regulate the masses. The masses are people who take action to obey state regulations.

Mosca [1] said that in the ruling elite, when they are no longer able to provide the services needed by the masses, there will be changes in the social forces that exist in the people. Social change is something that cannot be avoided, so a mass movement emerges that cannot be dammed by the elite. This mass movement can form a solid political force. Schumpeter [2] as Mosca [1] emphasized that democracy is actually government by the people, but in practice people are always governed by elites.

The people play a direct involved role in making improvements to political decisions on the prevailing system. In the past political decisions that changed people's lives were placed in the political policies of the executive elite and legislative elite, who were considered "understanding and knowing" the best of the people's needs. On the contrary, people are considered to be a group of "less understanding and less knowledgeable" in matters of state political decision making. But now in the modern era has changed, people are starting to react to all elite political decisions [3]. 


\section{Theoretical Framework}

Participation (as a verb) has meaning as an action in taking part of an activity, event, and event. The synonym for participation is involvement, participation, being part, having a contribution, being part of the association. Participation can be either active participation or passive participation from a person or group of people.

Political participation is the activity of a person or group of people to participate actively or passively in the process of state political life. Political participation can be done by the people by directly or indirectly choosing state leaders, influencing government policy, voting in general elections (in elections vote), attending a general meeting (attend a rally), holding bargaining power (contacting and lobbying) with government officials or board members, become party members.

Furthermore, what is meant by political participation in this research is the involvement of the people in influencing political decisions and government policies (public policy). Looking at the political context and referring to the participation of the people in various government political processes. The participation of the people in the government's political process does not only mean that the people support the decisions or policies outlined by their leaders, but the people can also reject the decision or policy.

If the people support, the right term is mobilized political participation, whereas on the contrary if the people do not support it means that the people do voluntary political participation without pressure from the authorities. Political participation here is specifically the involvement of citizens in all stages of policy, from decision making to decision evaluation, including opportunities to participate in the implementation of political decisions.

\section{Statement of the Problems}

Seeing the Kauman community and its efforts to maintain the near-extinct Dugderan market, there are many questions revealed in this study as follow: first, the researchers want to analyze how the Kauman people's community is raising their political participation so far? Second, how can the political participation of the local people change the government's political decision to maintain the market presence of Dugderan?

\section{Significance of the Study}

The Kauman people's community is one of the various community communities in Islam in the city of Semarang in the Kauman Village, Central Semarang District, Semarang City [4][5]. The city of Semarang has a multicultural and multi-ethnic society. The area of Kauman Village is one of 15 urban villages in the Central Semarang District (BPS Semarang City, 2015), which is inhabited by Arab-Javanese tribal communities.

The Dugderan market which was the focus of this study, at first, was marked by the emergence of traders' stalls which were arranged by the traders themselves a few days before the procession Dug Der [6]. However, because of the increasing number of mremo (seasonal business) traders, the Dutch government and the Semarang major at that time started to regulate and bring order to the traders around the mosque and front of the mosque. 


\section{Method}

Qualitative research approach was chosen. Attempted to find a phenomenon of popular political participation that has unique characteristics in detail and in depth about everything [7] relating to the administration of the Dugderan market as Semarang Mayor Decree No. 430/296 concerning the Establishment of the Semarang City Dugderan Organizing Committee in $1431 \mathrm{H} / 2010 \mathrm{M}$. The unique phenomenon in question is related to the case of people's participation in the administration of the Dugderan market, which appears only once a year in the Kauman region.

The main instrument in this study is the researchers themselves, as reviewed by Miles and Huberman (2002). In addition to supporting qualitative data obtained from informants (primary informants, secondary informants and supporting informants).

These informants are expected by researchers to be able to describe their involvement as civil society in the administration of the Dugderan market. While the speakers are expected researchers can provide insight and depth from research on the Dugderan market.

\section{Findings and Discussion}

An analysis of people's political participation in the implementation of Dugderan's market, based on Weiner [8] in Central Semarang District, is seen as follows; as Weiner says that modernization causes progress in all areas of life. Moreover, modernization stimulates the Kauman community to be more demanding in taking government political power when they determine Dugderan market location in 2016, 2017, 2018 and 2019 (The map location). Changes in social class structure shows that people in the modern era increasingly comprehend democratic values based on the voice of the people [9]. Likewise, the Kauman people understand the values of a developing democracy [10].

As a result, the people think that they were supposed to participate and elite the government who makes political decisions [11], in this case, Dugderan market location [12], which moves every year as noted in the Dugderan market map. Political decision which changes from year to year, becomes a condition of meaning and stimulates changes in political participation patterns from some figures [13] who came from the community of Kauman people. After reformation era, the 30-years-silent and passive people, now become more proactive and enthusiastic.

Recently, Dugderan location moves from one place to another, in order to adjust city planning, mall construction and various crowd considerations. The area around Central Java Grand Mosque (MAJT) which has the wide field, may become one alternative to move the bustling crowd of Dugderan to center of Dugderan to MAJT area.

Changes also occur at the time of implementation. The Semarang municipalities formerly became the center of the governance with full power who announced the beginning of Ramadhan to his people. Yet, the policy changes nowadays. The Semarang municipalities only follow the announcement from the central government from the Ministry of Religion in Jakarta. The announced day was not able to be predicted accurately. However, the Dugderan market was exhibited by the people a week or a few days before Ramadhan. Dugderan's market location changes were due to version differences in operating the as shown in the table 1 [14]. 
According to the facts found in this study, there are some organizations or associations that have a key role in the operation of Dugderan market [15]. Those who become key informants are key figures in economic, political and cultural activities of Kauman people. Primary informants (Table 1) are leaders from the elite of Kauman people (Muhaimin and A. Wahid, Agus N.), the elite committee of JPD (M. Djawahir) and the elite PPJP (Tobari and Mudzasir). They are triangle role relationships, which are very instrumental in the "golden" triangle relationship, the most caring and most maintaining market presence--Dugderan-- from extinction.

Political actors as a triangle role relationship who are related to the presence of the Dugderan market. They often demand something at the respective group level (Domhoff, 1990). There is politics of displacement or changes in Dugderan market location every year. This creates an opportunity for a triangle role relationship which affects Semarang municipalities' political decisions (especially, a particular agency that handles it). They are the Kauman community elite as civil society [16][17], in the end, they often get an invitation to attend meetings which are held by the government. Market Division is appointed division from Semarang municipalities to handle Dugderan market operation in 2016 and 2017 [18]. Meanwhile, in 2018 n 2019, the duty is replaced by the Trading Department.

Likewise the political participation of the Kauman community as Theory of Political Participation by Huntington and Nelson [19], that first, the political participation of the people of the Kauman community is more about various activities, instead of attitudes (political participation involves activities, not attitudes).Subjective components are referred to as political orientations which include political knowledge and experience, interest and desire for politics, feelings about competition and political effectiveness, as well as perceptions of political relevance. Political attitudes and feelings are only regarded as something related to a form of political action, but it is separated from the political action itself.

The subjects included in the political participation are citizens. The subject is a person per person in his role as an ordinary citizen. He is not per person as professionals in the field of state politics such as government officials, party officials, party candidates or prospective politicians. Subjects, who make political participation in this study, as mentioned in the table above, are person per person. Activities carried out by the subjects as an actor of political participation is un-continuous, or disjointed. It means that the participation is only as timeconsuming secondary job for the whole 1 to 3 months before Ramadhan in each year.

The three activities of political participation are intended to influence government decision making. This activity is mainly aimed to government officials who have political authority. The goal is to change11decision of the official in power, to replace or retain officials thus, to change or maintain the organization of the existing political system, and to monitor the rules of the political game so that it remains legitimate. The activities of the Kauman people's community political participation are intended to influence the decision making of the Semarang municipalities on the Dugderan market [20][21] as follows. The interview with Djawahir as has resulted the following issue:

"We have been asking for clarification from 2003-2004 and we convey many times of clarification and criticism related to the model of organizing traditional celebrations (Dugderan) and Dugderan market from the government version". He added, "We have been trying to make adjustments to the government's will that has facilitated the celebration of Dugderan, especially before Sukawi Sutarip (the Mayor) governance period. Yet, we--the Kauman community, have agreed and formulated issues related to of economic needs and interests for our lives. In this case, the celebration of Dugderan's tradition that includes a change in Dugderan's 
market location. Since this event is important for all people to signify the beginning of Ramadhan. Hopefully, the government could give more attention to the original Dugderan celebration and Dugderan market". (Interview with Djawahir, Chairperson of the Dugder Care Community (JPD) conducted at his home on March 5th, 2018).

In the end the Kauman people's community attended an official meeting and involved as a Dugderan committee established by the government. They finally obtained opportunity to clarify in annual meetings every held by government. In each official forum, the communication and active participation of the political actors are very important, especially between people who are affected by political decisions and the government that makes political decisions [22][23], regarding the implementation of the Dugderan market. Political decision making to determine the location, procession and timing of the Dugderan tradition has changed since the New Order era (Hadijanto, the mayor) until the reform era (Sutawi Sutarip, the mayor).

According to Arrow, it is a sign of mass stupidity [24], if there is a destruction of historical sites of Semarang city, like Semarang Regency Hall which was built hundreds of years ago. The extinction of Semarang Regency pavilion followed by the narrowing Semarang town square (alon-alon). Previously, the Alon-alon was more than 12 times football field large (before 1975). Yet, gradually it shrank due to the reckless policies of the government elites at that time. The elite of the Semarang municipalities at that time also changed the function of Semarang Alon-alon, which was formerly from Ya'ik market (popular since 1965), and part of the land was also used as a bemo terminal. The eastern part of the Alon-alon area, under the government permission, is Metro Hotels that still exists today.

As a result, Semarang Alon-alon area is in the form of terrain is lost, since it is now surrounded by wall buildings and other buildings. The current Alon-alon area in Semarang does not exceed the badminton court (it keeps narrowing since 1975 to 2016). Meanwhile the land above Semarang Alon-alon, which is actually included Kauman mosque area, has been surrounded by both permanent and semi-permanent buildings owned by traders of Ya'ik market. For that reason, Dugderan can no longer be held in the Semarang Alon-alon area, which is now smaller than a badminton court.

The selling location for traders in Dugderan event and playing arena have been removed from one place to another. It is not at one exact point anymore due to the existence of the Semarang City Regulation No. 14, 2011 that concerns the Semarang City Spatial Plan for 2011 to 2031.

Dugderan location has ever taken place on some streets, such as Agus Salim, Pemuda, Sugiyono, and the farthest venue was near Tawang train station which surely very far from Kauman. Kasturi illustrates that Dugderan is like a wreck item that may be thrown here and there [25].

The four political participations include all activities that can influence the government, regardless of whether the action has an effect or not, nor succeeded nor failed [26]. Political participation of Kauman community can apparently influence the government [27][28] and has an impact regarding the implementation of Dugderan market.

Even though the people of Kauman had clearly made autonomous participation, but they also did not refuse to follow government's political decision no.13, especially when the location of the Dugderan market had been decided. This means that they also support government's political mobilization political participation government [29] regarding the location shift of Dugderan market, whether it is at Tawang train station or near the new Johar 
market location. People's involvement on 2 types of participation as stated by Huntington \& Nelson [19].

\section{Conclusion}

Local traders who came from Kauman, Yaik, and Johar region were heading towards Dugderan location. They always wanted to attend and participate actively in the market to cherish the event. Besides, there arose growth of goodwill and good mind from folk figures to establish the Dugderan market. The existence of Dugderan market is a primary for marginal traders and the Kauman people as the preserver of Dugderan tradition in Semarang city.

Modernization makes Kauman people more demanding and proactive in taking part in the government's political power (Weiner, 2006), especially when determining Dugderan market location. Political decisions that changed from year to year, become a condition of meaning and resulting changes in patterns of political participation (TL Hadiati, 2013) to the Kauman community. Those who were originally silent and passive for 30 years, after the reform era became more proactive and aggressive. There was a conflict between groups of political leaders in the city of Semarang, so the existence of this market is not easy to develop, thus this issue is not easy to be decided and solved. This also becomes an opportunity for people to be involved in elite political decision making (Nicholson, 2011). Unfortunately, the people who wanted to convey valid information and alternatives regarding to Dugderan market itself, could only wait the government invitation to convey their aspiration in the government forums.

\section{Acknowledgements}

Funding to support the research for this article was provided by the Ministry of Research, Technology and Higher Education of the Republic of Indonesia and the 17 August 1945 University Semarang block grant system. The authors would like to thank the anonymous reviewers for their comment.

\section{References}

[1] G. Mosca, The Ruling Class. Westport: Greenwood Press, 1896.

[2] J. A. Schumpeter, Capitalism, socialism and democracy. routledge, 2013.

[3] H. Antlöv, D. W. Brinkerhoff, and E. Rapp, "Civil society organizations and democratic reform: Progress, capacities, and challenges in Indonesia," in RTI International, Paper presented at the 37th Annual Conference, Association for Research on Nonprofit Organizations and Voluntary Action, Philadelphia, 2008, pp. 20-22.

[4] A. S. Budiarto, "Concept of self-conservation in a traditional village: an empirical study of Kampong Kauffman Semarang Indonesia,” Nternational Trans. J. Eng. Manag. Appl. Sci. Technol. Int. Trans. J. Eng. Manag. Appl. Sci. Technol., vol. 7, no. 1, pp. 21-34, 2016.

[5] B. A. Suprapti, E. Budihardjo, N. H. Kistanto, and A. E. Tungka, "Ethnography-Architecture in Kampong Kauman Semarang: A Comprehension of Cultural Toward Space," Am. J. Eng. Appl. Sci., vol. 3, no. 3, 2010.

[6] D. Muhammad, Semarang Sepanjang Jalan Kenangan. Kerjasama Pemda Kodia Semarang [dengan] DKJT [dan] Aktor Studio, 1995.

[7] W. Creswell Jhon, "Reseach Design Pendekatan Kualitatif, Kuantitatid dan Mixed." Pustaka Pelajar. Yogyakarta, 2013. 
[8] M. Weiner, Modernisasi Dinamika Pertumbuhan. Yogyakarta: Gama University Press, 2006.

[9] L. G. Vergara, "Elites, political elites and social change in modern societies," Rev. Sociol., no. $28,2013$.

[10] N. Azizah, "PERUBAHAN SOSIAL, BUDAYA DAN EKONOMI DI KAMPUNG KAUMAN SEMARANG 1962-1998.” UNIVERSITAS NEGERI SEMARANG, 2015.

[11] E. N. Angmor, "Can Traditional Markets be improved through transportation service:(The case of Asesewa and Agormanya Traditional Markets, Ghana)," Int. J. Acad. Res. Bus. Soc. Sci., vol. 2, no. 6, p. 366, 2012.

[12] B. Pukrik, "The Revitalization of The Old Market in Thailand," Shalpakaron Univ., 2010.

[13] B. G. Bishin, R. R. Barr, and M. J. Lebo, "The impact of economic versus institutional factors in elite evaluations of presidential progress toward democracy in Latin America," Comp. Polit. Stud., vol. 39, no. 10, pp. 1194-1219, 2006.

[14] T. L. Hadiati, Perayaan Tradisi Dugderan Di Kota Semarang \& Deliberasi Politiknya. Semarang: Pustaka Magister, 2019.

[15] A. Ariya, "Tasty Local Market vs Mega Store: Dilemma of Cultural Landscape Preservation in Thailand," Sess. Prot. Nat. Cult. Resour., 2010.

[16] M. Edward, "NGO Rights and Responsibilities: A New Deal for Global Governance London: The Foreign Policy Centre." NCVO, 2000.

[17] M. Edward, Civil Society. USA: Polity Press in association with Blakckwell Publishing Ltd, 2008.

[18] P. G. Bakti, "Pendapatan Retribusi Pasar, LSM Pattiro: Pusat Telaah dan Informasi Regional, Semarang," 2013.

[19] S. P. Hungtington and J. Nelson, "Partisipasi Politik di Negara Berkembang Terjemahan Sahat Simamora." Jakarta: Penerbit PT. Rineka Cipta, 1990

[20] J.-R. Choi and D.-G. Lim, "A case study of cultural space to revitalize local community," Int. J. Hist. Cult., vol. 1, no. 1, pp. 1-14, 2013

[21] G. Arganata, "STRATEGI PEMENANGAN PASANGAN INCUMBENT PADA PEMILUKADA SERENTAK TAHUN 2015 di KABUPATEN LAMONGAN (Studi pada pasangan Fadeli dan Kartika Hidayati)." University of Muhammadiyah Malang, 2018.

[22] Esther and Didik, Membuat Pasar Tradisional Tetap Eksis. Jakarta: Sinar Harapan, 2003.

[23] H. Malano, Selamatkan pasar tradisional. Gramedia Pustaka Utama, 2013.

[24] C. James and D. P. Levine, Theories of Political Ekonomi. Cambridge: Cambridge University Press, 1992.

[25] S. P. B. Kasturi, "Dugderan Dari Masa ke Masa," Semarang Disbudpar Kota, 2010.

[26] M. A. Seligson and M. Corral, "When Education Doesn't Matter, Are Elites Still More Tolerant than Masses? A Natural Experiment in Bolivia.".

[27] R. Michels, Political parties: A sociological study of the oligarchical tendencies of modern democracy. Hearst's International Library Company, 1915.

[28] H. Suyatna, "Dominasi Elite Lokal Dalam Arena Pengembangan Industri Kecil di Era Desentralisasi," Dalam Maj. Prism. Perselingkuhan Bisnis Polit., 2012.

[29] S. Bolgherini, "Participation" dalam Mauro Calise and Theodore J. Lowi," Hyperpolitics An Interact. Dict. Polit. Sci. Concept, p. 169, 2010. 


\section{Appendix}

Table 1. Political Participation of the Community of Kauman People

\begin{tabular}{|l|c|c|c|c|c|}
\hline \multirow{2}{*}{$\begin{array}{c}\text { Name of Association or } \\
\text { Organization }\end{array}$} & Subject & $\begin{array}{c}\text { Knowledge } \\
\text { and } \\
\text { Experience in } \\
\text { Politics }\end{array}$ & $\begin{array}{c}\text { Interest and } \\
\text { Political } \\
\text { Willingness }\end{array}$ & $\begin{array}{c}\text { Political } \\
\text { Competition }\end{array}$ & $\begin{array}{c}\text { Political } \\
\text { Effectiveness }\end{array}$ \\
\hline $\begin{array}{l}\text { Kauman Mosque } \\
\text { Committee/Religious Power }\end{array}$ & Muhaimin & $\checkmark$ & $\checkmark$ & $\checkmark$ & $\checkmark$ \\
\hline $\begin{array}{l}\text { Kauman Mosque } \\
\text { Committee/Cultural Power }\end{array}$ & $\begin{array}{c}\text { Ahmad Wahid, } \\
\text { Agus Nurohman }\end{array}$ & $\checkmark$ & $\checkmark$ & $\checkmark$ & $\checkmark$ \\
\hline JPD/NGO Power & M. Djawahir & $\checkmark$ & $\checkmark$ & $\checkmark$ & $\checkmark$ \\
\hline PPJP/Economic Power & Mudzasir,Tobari, & $\checkmark$ & $\checkmark$ & - & $\checkmark$ \\
\hline Academic Power & Suroyo, Anggraeni & $\checkmark$ & $\checkmark$ & & $\checkmark$ \\
\hline
\end{tabular}

Source: Processed Data

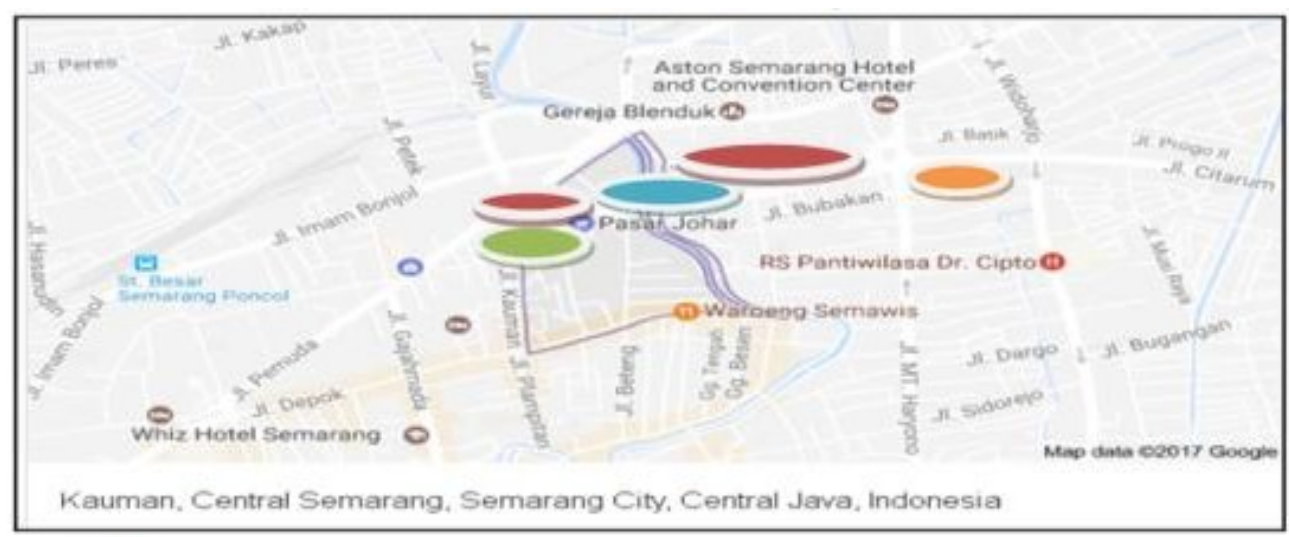

Remarks:

Dugderan Market in 2016

Dugderan Market in 2018

Dugderan Market in 2017

Dugderan Market in 2019

Fig. 1. The Map of Dugderan Market Location. 